\title{
Integrating Leadership into Futsal Training Program for Positive Youth Development
}

\author{
Gemi Candra ${ }^{1}$, Ruli Saepul Hayat ${ }^{2}$, Amung Ma'mun ${ }^{3}$, Nuryadi $^{4}$ \\ \{gemicandra.gc@gmail.com ${ }^{1}$, rullysaepulhayat7@upi.edu ${ }^{2}$, amung@upi.edu\} \\ Universitas Pendidikan Indonesia, Bandung, Indonesia ${ }^{1,2,3,4}$
}

\begin{abstract}
This study aims to determine the difference in leadership development among a group of futsal players that was integrated with leadership and not. The research used a quasi-experimental research method with The Matching-Only Pretest-Posttest Control Group Design. Samples were taken using purposive sampling technique which was divided into three groups. Analysis of the effect of leadership treatment into the futsal training program was carried out with one way ANOVA and further tests with Scheffe and the $t$ test. Based on the results of data processing and analysing, there was the effect of development in the group that were integrated with leadership as much 98.78. Analysis of the effect of leadership treatment was done by Gain Score. The result of leadership treatment effect analysis was the group that was integrated with leadership gave the effect towards leadership development as much $77,18 \%$ that was included in effective category.
\end{abstract}

Keywords: integrating, leadership, positive youth development, futsal

\section{Introduction}

It has been studied that global economic activity will be in a strict competition. more than that, it also has been stated that global economy will always change follows the era. as the result, it will provide challenges for young people to learn more in order to improve their abilities and life skills. furthermore, young people have been demanded to master some abilities and also developed life skills as a provisons in a real competetition in the future [1]. Related to the statement before, L. D. Cronin \& Allen, (2016) stated that life skills are the skills needed to face the demands and challenges found in daily life [2]. In addition to the skills aspect, life skills also include other physical aspects such as healthy eating patterns, aspects of knowledge (cognitive) that includes self-talk, and also behavior that includes goal setting [3].

Leadership as one of the life skills contained in sports becomes one of the basic aspects of sport, especially in team sports performance, although basically leadership also applies in various fields and contexts [4]. Leadership plays a role in motivating and encouraging team members to maximize the potential contained in the team, by being able to influence the confidence of team members, athlete leaders hold the key to optimal team performance [5]. The role, strategy, and tactics of a leader is very influential on the achievement that will be 
obtained by a group, but the role of each group member still cannot be eliminated [6]. The leader must not only develop the environment, but also relate directly to psychological and social aspects that have a direct effect on motivation.

Leadership has great significance in creating high performance and building team loyalty in sports. Every team or group of the most talented players will not always win sports games. In other words, talent is not decisive in a sports game. What is considered more important than talent is better than the players needed as a whole team. For this reason, an optimal process is needed [7]. Thus, everything related to leadership produces the final results that will be obtained, for example regarding the choice of leadership style, the better the leadership system, the better the results will be obtained. This is evidenced by various studies which state the significant importance in sports and leadership [8]. Some leadership is one part of life skills that are against sports, as well as it is against life. Hardcastle et al (2015) suggested that youth sports programs have a positive impact on the development of young people by helping them learn about themselves and to develop life skills [9].

Starting from a number of previous studies stated that learning life skills; in this case leadership skills can be included in sports teaching programs that are centered on specific sports skills. However, it has been suggested for programmers to be more serious about life skills learning by compiling specifically sports programs that teach life skills, so that even youth development can be encouraged. One of the goals of sports learning is also achieved, namely the application of values contained in sports into life daily [11].

The last few decades sport has become a means of positive youth development (PYD) [12]. In other words, the development of Youth in good terms has become the ultimate goal that is expected to be achieved through sports. As has been stated by Hold (2016) that sports have been arranged in such a way as to be able to foster positive youth development (PYD). Researchers in the field of sports psychology have worked hard to better understand how sport can be used as a medium to encourage positive youth development [13]. In the research conducted by Yoshitaka Iwasaki (2015) it was further discussed that there are three core concepts related to positive youth development (PYD). The three concepts are stated as follows, firstly the empowerment approach is based on strength in order to engage youth, secondly the development of capacity or skills and positive outcomes (in accordance with what is desired) for youth and institutions that serve youth, and finally the youth-oriented research process and collaborative nature that is expected to help this positive outcome [14].

Based on the theories stated earlier, positive youth development (PYD) can be stated to revolve around various development competencies needed by youth for personal, social and system needs to be able to become productive and contributing members of society [15]. Furthermore, positive youth development (PYD) pays special attention to the physical, personal, social, emotional, intellectual and spiritual development of youth, and emphasizes youth's strengths, resources and potential. On the other hand, positive youth development (PYD) is not only considered as the end result of a change process, but also as a strengthbased approach used to explore youth development, in this case youth is seen as a resource that will be developed not a problem that is a solution must be found [16].

Leadership as one of life skills contained in sports has become one of the basic aspects of sports, especially in team sports performance, although, basically leadership also applies in various fields and contexts [17]. Leadership is expressed as a result of combining skills and knowledge in a group of people with specific goals and motivating individuals to achieve certain goals. The role, strategy, and tactics of a leader is very influential on the achievement 
that will be obtained by a group, but the role of each group member still can not be ignored [18].

There are many sources stated the role of sports as an introduction for someone to achieve good goals, namely life skills. where, one of those skills is leadership. Life skills have been interpreted broadly as a skill needed in dealing with the demands and challenges in daily life [19]. Therefore, sport has been considered as a means that can support youth development in good terms [20]. A perception that attached to this definition is the skills learned in sports are considered as life skills, so it must be transfered and applied in daily life [21].

Sport has been identified as an effective intermediary for learning life skills. Many researchers (e.g. Bean \& Forneris, 2016; Camiré \& Kendellen, 2016; Turnnidge, Côté, \& Hancock, 2014) have discussed the importance of using a planned approach to youth development. As a life skill chosen in this research, it is known that the process of integrating leadership into sports requires a well-planned approach. For this reason, there are four principles that are expected to help integrating leadership into sports training program. The first principle is (a) focus on leadership in each meeting, this principle aims to maximize the leadership teaching process during the meeting. Besides, teaching leadership can be carried out with two or more meetings in order to achieve successful leadership learning. Moreover, the difficulties encountered at the first meeting can be identified then corrected at the next meeting. The second principle is (b) introducing leadership at the beginning of meeting. It must be done appropriately, where to introduce leadership it is necessary to allocate time clearly. The introduction of leadership must be combined with the introduction of skills in the game of futsal itself. Then the third principle is (c) applying strategies to teach leadership throughout the lesson. The use of strategies in teaching leadership is considered as a necessary aspect, because it can provide opportunities for group members to be able to practice the life skill through predetermined sports, where in this study the sport used is futsal. For this reason, trainers are expected to integrate two types of strategies in the learning process. The first strategy must involve a combination of leadership with activities in futsal itself. The second strategy is some specific activities that are related to leadership, for example through a group game. Then the last principle is (d) evaluating leadership at the end of the lesson. Technically, trainers must provide 2 up to 5 minutes at the end of the learning process to evaluate leadership. The evaluation meant is an explanation of the application of leadership as the life skill that have been learned through futsal into daily life. In addition, the evaluation can also be carried out by giving brief questions about what has been learned as a reflection and reinforcement of the relationship between sports and life. Furthermore, in order to get a clear picture and to make it easier in applying the life skill (leadership) into daily activities, trainers should provide a concrete example of how leadership can be applied into daily situations [22].

Starting from a number of previous studies stated that learning life skills; in this case learning leadership skills can be contained in sports teaching programs that are centered on certain sports skills [23]. However, it has been suggested for teachers to be more serious about learning life skills by specifically developing sports programs that teach life skills, so that youth development can be encouraged [24], moreover, one of the goals of sports learning is achieved, namely the application of values contained in sports into daily life.

However, there is only a few research that explain how the process of transferring life skills in sports to be applied into any fields. in this case, there are two approaches revealed that can be used, the first is an implicit approach, where life skills are suggested to be taught through sports programs that focus on specific sports skills. the assumption that when learning special sports skills, an athlete can basically learn other skills implicitly which can then be 
useful in any fields. The second approach is an explicit approach which suggests that life skills must be taught systematically with leadership programs. The program in question is a sports program that is well designed to provide specific guidance on how life skills can actually be transferred to daily life, where in fact that life skills are currently only taught at the beginning, middle, or end of the learning process, which means the program is not well designed [25].

Cronin \& Allen, (2017) stated "some research shows that through sports, young people develop such as teamwork, goal setting, time management, emotional skills, communication, social skills, leadership, problem solving and decision making". The lack of research on the impact of leadership skills on sports makes researchers interested in examining more closely related leadership abilities. Therefore, researchers will conduct research on the theme of leadership integration into the futsal training program for Positive Youth Development (PYD) [26].

\section{Methods}

This type of research is quasi-experimental (Quasi Experiment Design). The research design used is the design of The Matching-Only Pretest-Posttest Control Group Design. The population in this study were members of futsal SMAN 16 Bandung and then members of Futsal SMA National and Bandung National High School students. The sample in this study was taken from the population that must be representative (represent). Sampling is based on a purposive sampling technique, taking into account age. For this reason, adolescents aged 1225 years were selected as samples.

In this study, research data were obtained using the Identity Leadershipp Inventory (ILI) questionnaire which was developed by NK Steffens et al (2014). The ILI questionnaire instrument consisted of 16 statement items containing leadership skills. The measurement scale used for this research instrument is a Likert scale with a seven-point scale range from 1 (not at all) to 7 (very much). Before using the instrument the researchers tested the validity and reliability using SPSS version 20 . With the results of the validity test using the $r$ count compared to the $r$ table, the results were $r$ count $>r$ table (0.404). Likewise, the reliability test results using the Cronbach's alpha value of the result $\alpha-0.361$ with a reliable decision.

Data processing in this study used quantitative methods with descriptive and inferential statistics. To analyze descriptive statistical data using statistical software assistance, namely SPSS version 20. Statistical prerequisite tests include normality and homogeneity tests using SPSS version 20. Analysis of the effect of leadership treatment into futsal training programs is carried out with one way ANOVA and further tests with Scheffe and the test $\mathrm{t}$ (independent sample $t$ test). Meanwhile, to determine the effectiveness of the use of a method or treatment in this study using the Gain score test.

\section{Results and discussions}

This research consisted of three groups as the sample which is divided as follows, group A is a group of futsal players who were integrated with leadership model, Group B is a group 
of futsal players who were not integrated with leadership model, and Group C is a group that did not participate in futsal altogether and were not integrated with leadership model, Where the Data obtained from each group before the treatment (pretest) and after treatment (posttest) perform as follows.

Table 1. Descriptive statistics of research results

\begin{tabular}{rlrr}
\hline \multicolumn{2}{c}{ Research Group } & N & Average \\
\hline \multirow{2}{*}{ A } & Pretest & 27 & 53.93 \\
& Posttest & 27 & 98.78 \\
\hline \multirow{2}{*}{ B } & Pretest & 24 & 37.96 \\
& Posttest & 24 & 37.96 \\
\hline \multirow{2}{*}{ C } & Pretest & 20 & 25.10 \\
& Posttest & 20 & 25.30 \\
\hline
\end{tabular}

Based on Table 1, it was known that the average pretest score of group A was 53.93 and its average posttest score was 98.78, while the average pretest score of Group B was 37.96 and its average posttest score was 37.96, and then the average pretest score of Group C 25.10 and its average posttest score was 25.30 .

After the prerequisite test was fulfilled, the hypothesis test was then conducted. The first hypothesis test in this research used the One Way Anova test while the second, third, and fourth hypothesis test used the t test, namely the independent sample $t$ test. All of the tests used SPSS ver. 20.

Table 2. One Way Anova Test Results

Leadership Measurement
\begin{tabular}{|l|r|r|r|r|r|}
\hline & \multicolumn{1}{|c|}{$\begin{array}{l}\text { Sum of } \\
\text { Squares }\end{array}$} & \multicolumn{1}{c|}{ df } & Mean Square & \multicolumn{1}{c|}{ F } & Sig. \\
\hline Between Groups & 75905.893 & 2 & 37952.947 & 4908.098 & .000 \\
Whanin Groups & 525.825 & 68 & 7.733 & & \\
Total & 76431.718 & 70 & & & \\
\hline
\end{tabular}

It showed that sig $0.000<0.005$, it declared there was a difference, then $\mathrm{H} 0$ was rejected. It meant that there were differences in the leadership development of each group.

To see the similarity in the average results of leadership abilities in each group, the output of "Uji Scheffe.a.b " was used. 
Table 3. Hasil uji Scheffe ${ }^{\text {a.b }}$

Penilaian Kepemimpinan

\begin{tabular}{|c|c|c|c|c|}
\hline \multirow[b]{2}{*}{ Kelompok } & \multirow[b]{2}{*}{$\mathrm{N}$} & \multicolumn{3}{|c|}{ Subset for alpha $=0.05$} \\
\hline & & 1 & 2 & 3 \\
\hline $\begin{array}{l}\text { Tidak Ikut Olahraga dan } \\
\text { tidak diberi Integrasi } \\
\text { Kepemimpinan }\end{array}$ & 19 & 22.58 & & \\
\hline $\begin{array}{l}\text { Ikut Olahraga tanpa } \\
\text { Integrasi Kepemimpinan }\end{array}$ & 23 & & 34.96 & \\
\hline $\begin{array}{l}\text { Ikut Olahraga diintegrasi } \\
\text { Kepemimpinan }\end{array}$ & 26 & & & 94.50 \\
\hline Sig. & & 1.000 & 1.000 & 1.000 \\
\hline
\end{tabular}

Based on Table 3, it showed that at the significance level $\alpha=0.05$ the average coefficient of each group was in a different column. Statistically, it meant that there was a difference in the average ability of the leadership of each group.

The average coefficient that was greater than the average coefficient of the other groups was the group that participated in sport and was also integrated with leadership model, the average score was 98.78. it showed that the ability of leadership in the group of futsal players who were integrated with leadership model was better than the other groups.

Furthermore, As for knowing the difference in leadership development between the group of futsal players who were integrated with leadership model and the group of futsal players who were not integrated with leadership model can be seen in Table 4.

Table 4. The results of independent sample t test for group A and group B

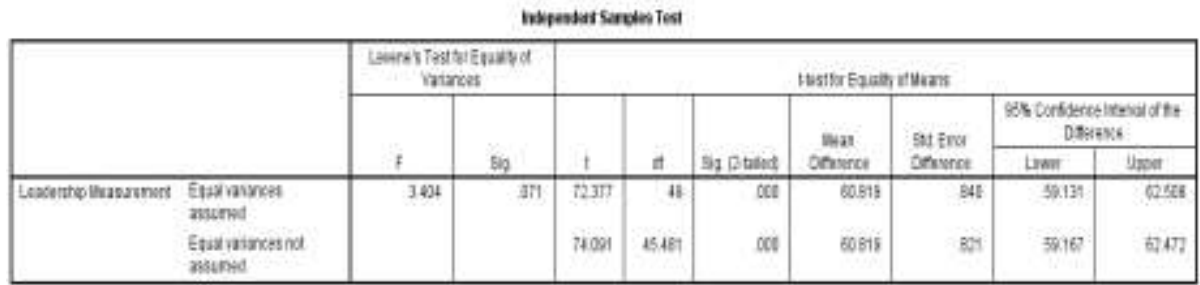

Based on Table 4, it was known that the Sig (2-tailed) value was $0,000<0.05$, then it can be stated that there was a difference, which meant $\mathrm{H} 1$ was accepted and $\mathrm{H} 0$ was rejected. This meant that there were differences in leadership abilities between those who participate in sport and were integrated with leadership model and those who participated in sport, but were not integrated with leadership model.

Furthermore, the third hypothesis test was conducted to find out whether there are differences in leadership development between the group of futsal players who were integrated with leadership model and the group that did not participate in futsal altogether and were not integrated with leadership model. The result can be seen in Table 5. 
Table 5. The results of independent sample $t$ test group A and group $C$

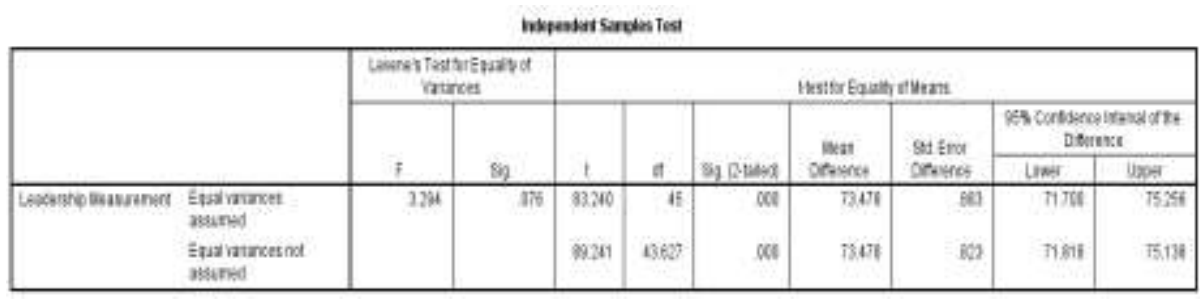

Based on Table 5, it was known that Sig (2-tailed) value was $0.000<0.05$, where it can be stated that there was a difference. Therefore, $\mathrm{H} 1$ was accepted and $\mathrm{H} 0$ was rejected. This meant that there were differences in leadership abilities between those who participated in sport and were integrated with leadership model and those who did not participate in sport and were not integrated with leadership model.

Furthermore, The fourth hypothesis test was conducted to find out whether there are differences in leadership development between the group of futsal players who were not integrated with leadership model and the group that did not participate in futsal altogether and were not integrated with leadership model. The result can be seen in Table 6 .

Table 6. The results of independent sample t test for group B and group C

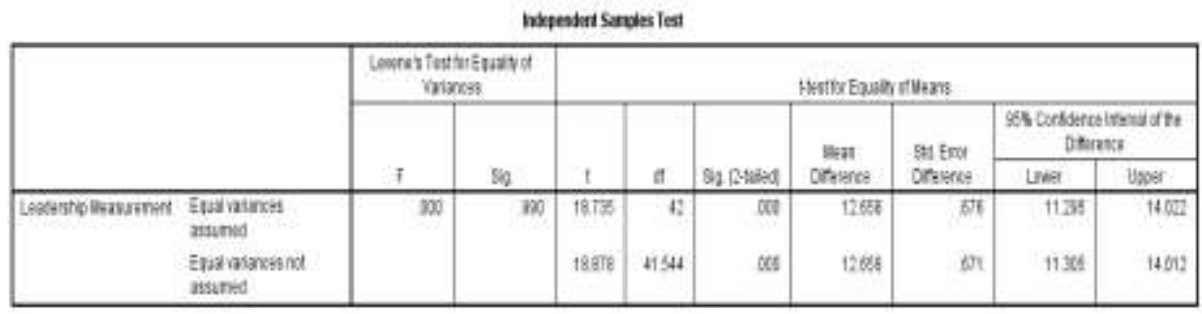

Based on Table 6, it was known that the Sig (2-tailed) value was $0,000<0.05$, then it can be stated that there was a difference, where $\mathrm{H} 1$ was accepted and $\mathrm{H} 0$ was rejected. This meant that there were differences in leadership abilities between those who participated in sport without any integration of leadership model and those who did not participate in sport and also were not integrated with leadership model.

In addition, Gain score test was carried out to determine the effectiveness of a method or treatment used in this research. The result can be seen in Table 7.

Table 7. Gain score test results

\begin{tabular}{|c|c|c|c|c|c|}
\hline \multicolumn{2}{|c|}{ Kelompok A } & \multicolumn{2}{|c|}{ Kelompok B } & \multicolumn{2}{|c|}{ Kelompok C } \\
\hline \multicolumn{2}{|c|}{ Gain Score (\%) } & \multicolumn{2}{|c|}{ Gain Score (\%) } & \multicolumn{2}{|c|}{ Gain Score $(\%)$} \\
\hline Average & 77,1854 & Average & $-0,0014$ & Average & 0,1841 \\
\hline minimum & 64,91 & minimum & $-2,78$ & minimum & $-5,81$ \\
\hline Maximum & 88,33 & Maximum & 2,82 & Maximum & 6,74 \\
\hline
\end{tabular}


Based on Table 7, it showed that the average Gain Score for the group that participated in sport and was integrated with leadership model was $77,1854 \%$, where the minimum Gain Score was $64.91 \%$ and the maximum of $88.33 \%$. therefore, it can be stated effective.

Furthermore, the average Gain Score for the group that participated in sport and was not integrated with leadership model was - 0,0014\%, where the minimum Gain Score was $-2,78 \%$ and the maximum was $2,82 \%$, so it can be stated as ineffective. Meanwhile, the average Gain Score for those who did not participate in sport and were not integrated with leadership model was $0,1841 \%$, where the minimum $\mathrm{N}$-Gain Score was $-5,81 \%$ and the maximum was $6,74 \%$. it was also stated as ineffective.

Therefore, it can be concluded that those who participated in sport and were integrated with leadership model based on the data from self-assessment are effective for enhancing leadership abilities, while those who participated in sport without any leadership model integration, and those who did not participate in sport and were also not integrated with leadership model were not effective in increasing leadership abilities.

Hypothesis test results indicated that there are differences in leadership development in each group (Table 2). The HSD tukey test (Table 3) showed that the leadership abilities of the group that participated in futsal training and was integrated with leadership model were better than the other groups. The difference between the two can be seen in Table 3 shows that leadership development that follows integrated sports leadership is better than groups that is without integrated leadership. The results found are in accordance with the statement made by Gould \& Carson (2008) which stated that sport can be used to improve life skills and positive youth development. the Futsal players who participated in leadership programs treated can improve their leadership skills, more than that the existence of leadership training can be considered as an effective model for leadership learning [27].

Leadership for students who participate in futsal training activities can be considered as a very beneficial skill for them for living in the community, because leadership as a result of the combination of skills and knowledge in a group of people with specific goals and expected to motivate individuals to achieve goals. Leadership can be integrated into futsal training programs, because sport is one of the most popular recreational activities for young people. Hardcastle et al (2015) suggested that youth sports programs have a positive impact on the development of young people by helping them to learn as to themselves and to develop life skills [28].

The leadership development of futsal players that given a treatment and those who were not given any treatment, can be seen in Table 4. the leadership abilities of Each group were different. The data showed that the development of leadership abilities in the group that given a treatment is greater than those who were not given any treatment. it is because of the leadership of futsal players that given treatment is systematically and deliberately arranged, so that at every meeting there is always integration of leadership programs. The result of this research is equal to the result of a research conducted by Bean \& Forneris (2015) that a deliberately structured programs have better results compared to unstructured and unintentional programs [29].

The leadership development of futsal players that integrated with leadership model, and those who did not participated in futsal training and were not given any treatment, can be seen in Table 5. There was a difference between the leadership abilities of those who were given a treatment compare to those who did not participated in futsal training and were not given any treatment. 
The above statement is supported by the statement of Bakoban \& Aljarallah (2015) which states that "the various experiences gained from following extracurricular activities are able to have a positive impact on students' emotional, intellectual, social and interpersonal development". So interacting and working with others can have a positive impact such as leadership abilities [30].

The leadership development of futsal players that were not given any treatment and those who did not participated in futsal training and were not given any treatment, can be seen in Table 6. There was a difference of leadership ability in those two group. The data showed that the leadership development in the firstly mentioned group was slightly higher than the other group. The result is equal to what was stated by (Turnnidge, Côté, \& Hancock 2014), regarding the implicit approach, where life skills are taught through sport programs that focus on specific sport skills. The assumption that when learning specific sport skills, an athlete basically can also learn other skills implicitly, it is related to the leadership abilities of futsal players that were not given any treatment still increased compare to the group that did not participated in futsal training and were not given any treatment [31].

For the final step, the researcher conducted gain score test to determine the effectiveness in the usage of a method or treatment in this research, it can be seen in Table 7 where it showed that the average score of the gain score for the leadership of futsal players that given a treatment is $77,1854 \%$ where it can be included into the "effective" category.

Thus, it can be concluded that the leadership of futsal players that given a treatment is effective to improve leadership abilities, while the leadership of futsal futsal players that were not given any treatment and those who did not participate in sport and were also not given any treatment stated as ineffective in developing leadership abilities.

This research shows that the importance of teachers or trainers to integrate the program systematically and deliberately in sports, and they are expected to not just focused on the technique, so that the results obtained are achieved well and can help develop their abilities.

\section{Conclusions}

The results of data processing and analyzing shows the differences in the leadership development of futsal players through futsal activities. Therefore, it can be concluded that the leadership development of futsal players that integrated with leadership program is better compared to the leadership development of futsal players that were not integrated with leadership programs and those who did not participate in futsal and were not integrated with leadership program. This leadership development can be implemented in daily life other than sport context and also can provide opportunities to experience positive youth development process.

Considering the importance of the content raised in this research, but there are still limitations in, then it is expected that there will be other researchers who can conducted a research to complete this research in the future. For further researchers, this research is expected to be a reference, so that it can be developed with enlarged variables and problems.

\section{Acknowledgments}

With the completion of this research, the author would like to thank Dr. Amung Ma'mun, M.Pd as the main supervisor and Mr. Nuryadi, M.Pd as supervisor. 


\section{References}

[1] Gould, D., \& Carson, S. (2008). Life skills development through sport: current status and future directions. International Review of Sport and Exercise Psychology, 58-78.

[2] Cronin, L. D., \& Allen, J. (2016). Author Note. Psychology of Sport \& Exercise.

[3] Hardcastle, S. J., Tye, M., Glassey, R., \& Hagger, M. S. (2015). Exploring the perceived effectiveness of a life skills development program for high-performance athletes. Psychology of Sport \& Exercise, 16, 139-149.

[4] Cotterill, Stewart T., \& Fransen, Katrien. (2016). Athlete leadership in sport teams: Current understanding and future directions.

[5] Fransen, Katrien, dkk. (2014). The Impact of Athlete Leaders on Team Members' Team Outcome Confidence: A Test of Mediation by Team Identification and Collective Efficacy. The Sport Psychologist p.2

[6] Devecioğlu, Sebahattin.(2018). The Leadership Orientations of the Students Receiving Sports Education in Turkey. Canadian Center of Science and Education, 1.

[7] Cotterill, S. (2013). Team psychology in sports: Theory and practice. Abingdon: Routledge.

[8] Atan, T., Ünver, Ş., Kaplan, A., İslamoğlu, İ., \& Demir, G. (2018). Comparison of leadership levels of students at the faculty of sport sciences and other faculties. Universal Journal of Educational Research, 6(6), 1313-1316. https://doi.org/10.13189/ujer.2018.060622

[9] Hardcastle, S. J., Tye, M., Glassey, R, \& Hagger, M. S. (2015). Exploring the perceived effectiveness of a life skiils development program for high-performance athletes. Psycology of sport and exercise, 16 (P3), 139-149.

[10] Chinkov, A. E., \& Holt, N. L. (2016). Implicit Transfer of Life Skills Through Participation in Brazilian Jiu-Jitsu. Journal of Applied Sport Psychology, 28(2), 139-153.

[11] Bean, C. N., Kendellen, K., Halsall, T., \& Forneris, T. (2014/2015). Putting program evaluation into practice : Enhancing the Girls Just Wanna Have Fun program. Evaluation and Program Planning, 49, 31-40.

[12] Holt,N.L.(2016).Positive youth development through sport (2nd ed.). London, UK: Routledge.

[13] Chinkov, A. E., \& Holt, N. L. (2016). Op.Cit

[14] Iwasaki, Yoshitaka.2015.The role of youth engagement in positive youth development and social justice youth development for high-risk, marginalised youth. International Journal of Adolescence and Youth

[15] Alicea, S., Pardo, G., Conover, K., Gopalan, G., \& McKay, M. (2012). Step-up: Promoting youth mental health and development in inner-city high schools. Clinical Social Work Journal, 40, 175186.

[16] Theresa Beesley \& Jessica Fraser-Thomas. 2019. Claims of positive youth development: a content analysis of mixed martial arts gyms' websites. Routledge

[17] Cotterill, Stewart T., \& Fransen, Katrien. (2016). Loc. Cit.

[18] Devecioğlu, Sebahattin.(2018). The Leadership Orientations of the Students Receiving Sports Education in Turkey. Canadian Center of Science and Education, 1.

[19] World Health Organization (1999). Partners in life skills education: Conclusions from a United Nations inter-agency meeting. Geneva: World Health Organization.

[20] Jones, Martin I, \& Lavallee, David (2009). Exploring perceived life skills development and participation in sport. Qualitative Research in Sport and Exercise Vol 1 No 1.

[21] Gould, D., \& Carson, S. (2008). Loc.Cit.

[22] Kendellen, K., Camire, M., Bean, C. N., Forneris, T \& Thompson, J. (2016). Integrating life skills into Golf Canada's youth programs: Insights into a successful research to practice partnership. Journal of Sport Psychology in Action, 1-13.

[23] Chinkov, A. E., \& Holt, N. L. (2016). Loc.Cit

[24] Bean, C. N., Kendellen, K., Halsall, T., \& Forneris, T. (2014/2015), Loc.Cit 
[25] Turnnidge, J., Côté, J. C., \& Hancock, D. J. (2014). Positive youth development from sport to life: Explicit or implicit transfer? Quest, 66, 203-217 (B).

[26] Cronin, L. D., \& Allen, J. (2017). Development and initial validation of the Life skills scale for sport. Psychology of Sport and exercise, 28, 105-119.

[27] Gould, D., \& Carson, S. (2008). Life skills development through sport: current status and future directions. International Review of Sport and Exercise Psychology, 1(1), 58-78.

[28] Hardcastle, S. J., Tye, M., Glassey, R, \& Hagger, M. S. (2015). Exploring the perceived effectiveness of a life skiils development program for high-performance athletes. Psycology of sport and exercise, 16 (P3), 139-149

[29] Bean, C. N., Kendellen, K., Halsall, T., \& Forneris, T. (2014/2015), Loc.Cit.

[30] Bakoban, R. A., \& Aljarallah, S. A (2015). Extracurricular activities and their effect on the students grade point average: Statistical study. Educational Research and Reviews, 10 (20), 27372744.

[31] Turnnidge, J., Côté, J. C., \& Hancock, D. J. (2014). Loc. Cit. 